\title{
IMPLEMENTATION OF TURBOCHARGER ON SINGLE CYLINDER DIESEL ENGINE AND VIBRATION ANALYSIS USING FFT
}

\author{
ANALYZER \\ Nagappa.Y.Tirlapur ${ }^{1}$, S Kumarappa ${ }^{2}$ \\ ${ }^{I} P G$ Student, Department of Mechanical Engineering, BIET Davangere, Karnataka, India \\ ${ }^{2}$ Professor and Head, Department of Mechanical Engineering, BIET, Davangere, Karnataka, India
}

\begin{abstract}
Turbochargers are used throughout the automotive industry as they can enhance the output of an internal combustion engine without the need to increase its cylinder capacity. The application of such mechanical device enables automotive manufacturers to adopt smaller displacement engines, commonly known as "engine downsizing". Historically turbochargers were often used to increase the potential of an already powerful IC engines. The emphasis today is to provide a feasible engineering solution to manufacturing economics and "GREENER" road vehicles. It is because of these reasons that turbochargers are now becoming more and more popular in automobile applications. The aim of the paper is to check feasibility of turbocharging single cylinder four-stroke internal combustion engine with modifications and vibration analysis of engine with both conditions of turbocharging and without turbocharging by FFT analyser.
\end{abstract}

\section{INTRODUCTION}

The automobile new era is the result of the accumulations of many years of pioneering research \& development.

"One of the biggest trends right now in automobile engineering is improving engine efficiency \& fuel economy". This includes downsizing, down-speeding, direct fuel injection \& boosting, weight reduction in vehicles subsystems is also being tested by using lightweight structures made from alternative materials such as aluminium, magnesium, composites plastics and multimaterial construction.

Emerging trends in automobiles engineering are

1) Downsizing

2) Advanced combustion modes

3) Turbocharging

A system to turbocharger single cylinder engines would be useful for a number of reasons. Turbocharging small tractors will allow lower weight, lower cost machines to be made, which could be affordable to small scale farmers who could not afford a conventional tractor and also turbocharged singles cylinder engines could be used on generator, motorcycles and anything else that needs a small engine.

A turbocharger uses pressurized exhaust gas from the engine to spin a turbine, which is connected to a compressor. The compressor pressurizes the ambient air, increasing its density. The dense air goes into the engine cylinder during the intake stroke. Since there is more oxygen as result of increased density of air in the cylinder, the engine can combust more fuel.This means that the engine gets more power out of every stroke.
The internal combustion engine design, itself is a complex task as it includes multiple parts of various sizes assembled together. Taking into account the consumer aspirations and surrounding considerations vibration reduction is at most important phenomenon. Four major causes for overall vibration behaviour of IC engine are variation in gas pressure in each cycle, impact forces due to reciprocating parts, unbalanced rotating and reciprocating parts and mount structural characteristics. Due to increase in volumetric efficiency by using turbocharger reduces the noise and smooth running engine is observed; which is analysed by using FFT analyser.

IC engines produce mainly two types of vibrations i.e. longitudinal and torsional vibrations. In which reciprocating behaviour of the engine results some torsional vibration continuously.

Thus to measure and minimize the engine vibrations a dynamic approach is needed. The experimentation is conducted on single cylinder diesel engine with turbocharger and without turbocharger.

\section{EXPERIMENTATION}

\subsection{Experimental Setup}

The kirloskar TV1 model single cylinder $5.2 \mathrm{~kW}$, water cooled DI engine with a bore of $87.5 \mathrm{~mm}$ and stroke of $110 \mathrm{~mm}$ and a compression ratio $17.2: 1$ of constant speed $1500 \mathrm{rpm}$ coupled to A.C generator of 240volts, 25amps computerized engine is used for the experiment. Waste gated turbocharger is implemented at exhaust with modification to operate engine on with or without turbocharger by providing bypass arrangement with control valves and oil is supplied from the engine by making $\mathrm{T}$ joint as shown in Fig. 1 
Intercooler is fitted at top side of the cylinder head to avoid heat flow and is used to increase the density of compressed air. The exhaust gas temperature is measured by temperature sensor of K-type thermocouple and pressure transducer is mounted on engine and connected to PC through cables to measure in-cylinder pressure.

A optical decoder and encoder is used to measure the speed fluctuation during the operation by setting the TDC and electrical load is applied on the engine by 100 watt, 200 watt bulbs setup. Separate air boxes are used to supply air for engine and control valve is used to check the turbocharging by controlling the air.

In the experimentation the vibration acceleration signatures are measured for engine without turbocharger and with turbocharger by mounting accelerometer on engine crankcase by using FFT spectrum analyser setup.

In the experimentation while taking readings an acceleration transducer having piezoelectric sensor is used, this is placed at crankcase. OROS is the platform used for vibration measurements; OR24 PC-Pack is a very compact and very powerful 4-channel analyser for noise and vibration measurements.

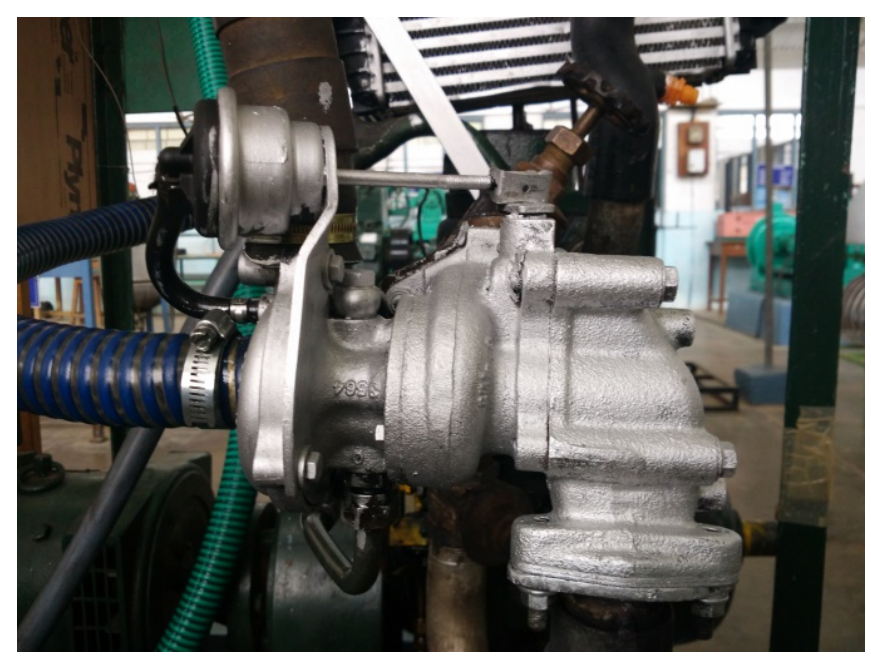

Table1 Engine specifications

\begin{tabular}{|l|l|}
\hline Model & TV \\
\hline Make & Kirloskar \\
\hline Power(kW) & 5.2 \\
\hline Speed(rpm) & 1500 \\
\hline Cylinder bore(m) & 0.0875 \\
\hline Stroke length (m) & 0.11 \\
\hline Connecting rod length (m) & 0.234 \\
\hline Compression ratio & 17.5 \\
\hline Stroke type & Four \\
\hline No of cylinders & One \\
\hline Speed type & Constant \\
\hline Cooling type & Water \\
\hline Fuel type & Diesel \\
\hline
\end{tabular}

\subsection{FFT Analyser}

FFT analyser is a batch processing device which samples the input signal for specific time interval by collecting the samples in a buffer, after which it performances the FFT calculations on that batch and displays the resulting spectrum. FFT analyser also called as spectrum analysis. It is defined as the transform of a signal from a time domain representation into a frequency domain representation.

\subsubsection{Block Diagram of FFT Analyser}

Fig.1. Experimental setup

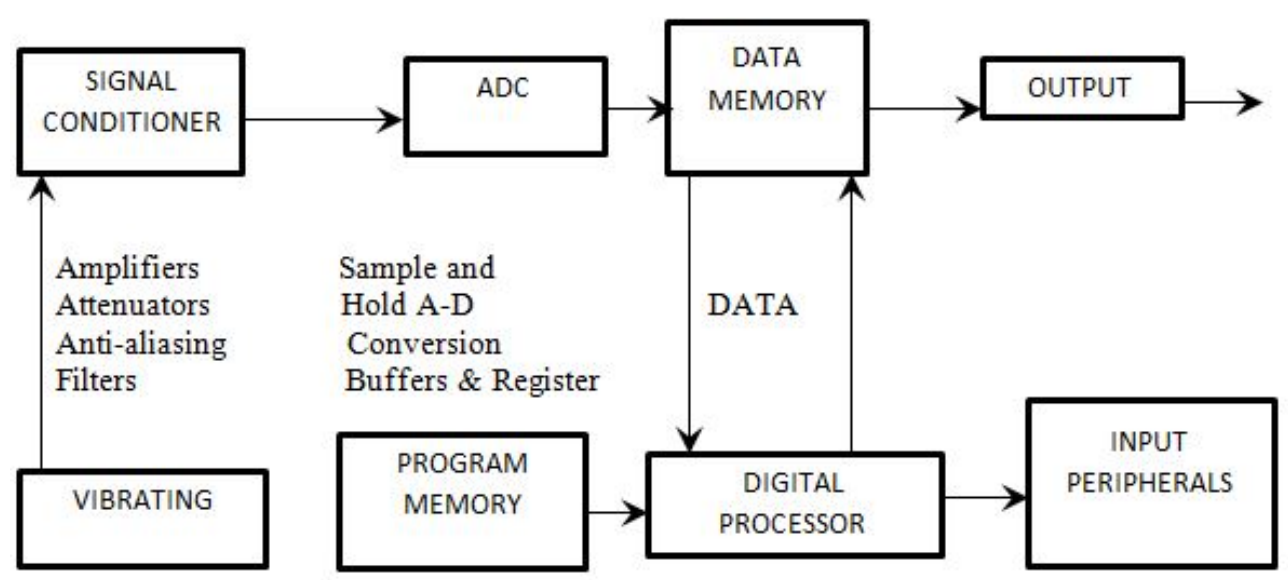

Fig.2. Block diagram of FFT Analyser 
Table 2 Specifications of the OROS software for the model OR-24

\begin{tabular}{|l|l|}
\hline Number of input channels & 2 or 4 \\
\hline Frequency Band & $20 \mathrm{kHz}$ \\
\hline Dynamic Range & $130 \mathrm{~dB}$ \\
\hline Through put rate & $4 \times 20 \mathrm{kHz}$ \\
\hline Digital Trigger/Tach & Up to $300 \mathrm{kHz}$ \\
\hline Dimensions & $250 \times 170 \times 45$ \\
\hline Weight & $2 \mathrm{~kg}$ \\
\hline
\end{tabular}

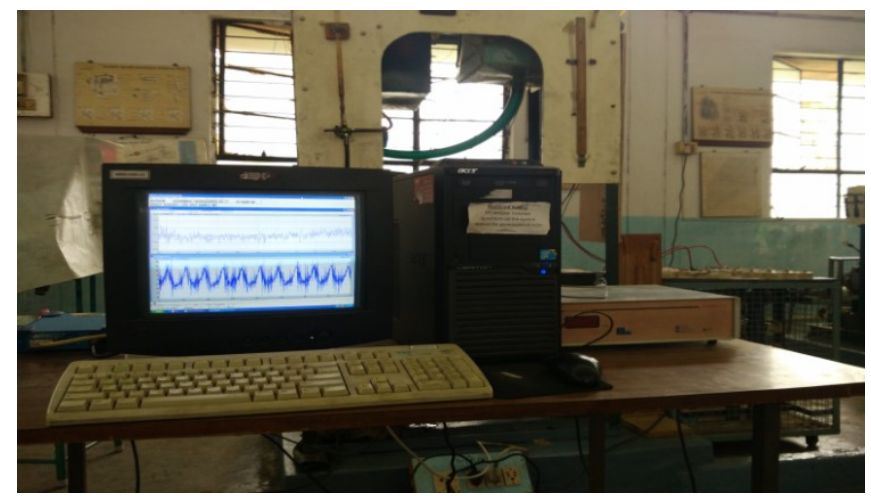

Fig.3.Running of OROS software for analyses

\subsection{Result and Discussion}

\subsubsection{Effect of Turbocharger on Performance}

\section{Parameters}

\section{1) Brake Thermal Efficiency (BTE)}

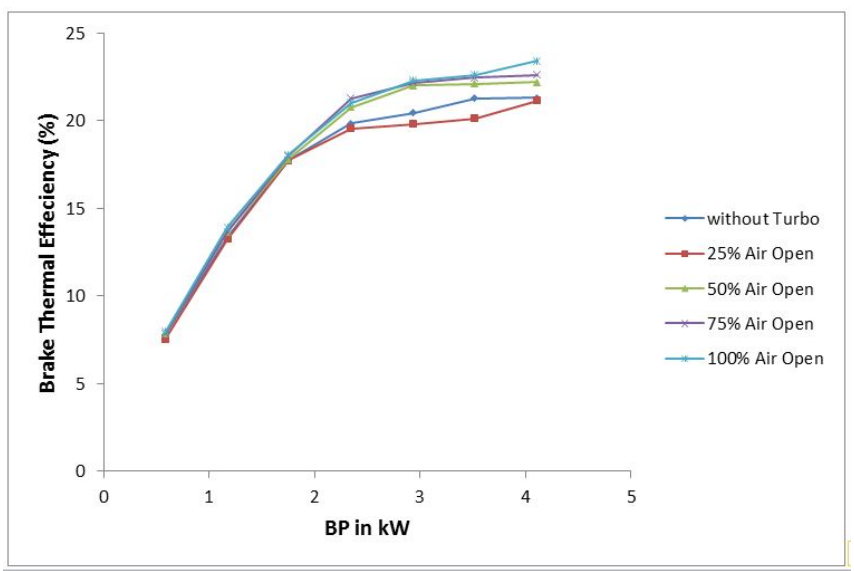

Fig.4.Variation of BTE with Brake power

The above Fig.4 shows that variation of brake thermal efficiency with brake power for engine without turbocharger and with turbocharger at four different inlet opening conditions for diesel as a fuel. Increase in brake thermal efficiency was observed for engine with turbocharger as compared to without turbocharge, due to more oxygen molecules for the combustion by sending compressed air by compressor. Thus for turbocharged engine of $100 \%, 75 \%$ and $50 \%$ air open at $4.11 \mathrm{~kW}$ of BP there is $2.09 \%, 1.3 \%$ and $0.91 \%$ increase in BTE is achieved; but for $25 \%$ air opening there is decreased BTE of $0.19 \%$ is observed because of more restriction of air flow.

\section{2) Brake Specific Fuel Consumption}

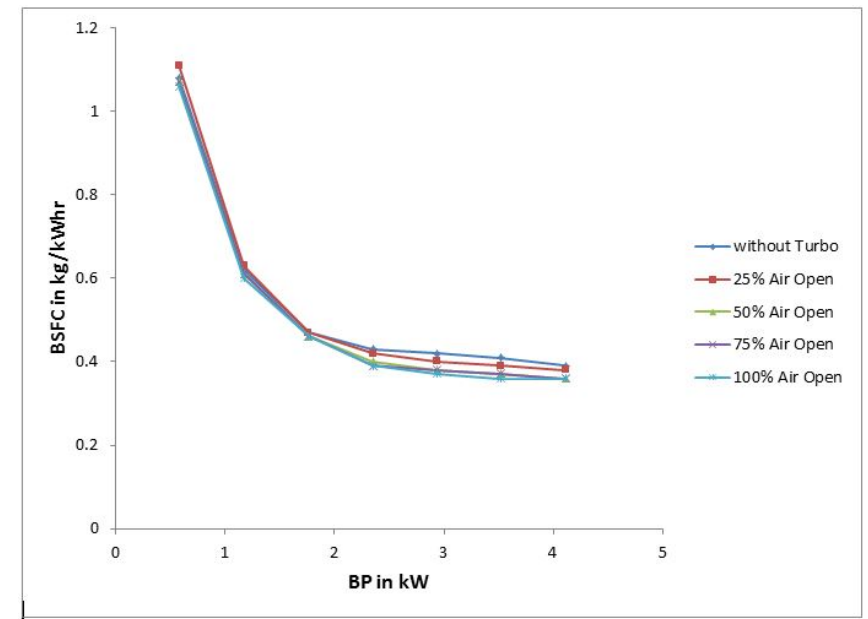

Fig.5 Variation of BSFC with Brake power

The above Fig. 5 shows that variation of brake specific fuel consumption with brake power for engine without turbocharger and with turbocharger at four different inlet opening conditions for diesel as a fuel. Engine with turbocharger for $100 \%, 75 \%$, and $50 \%$ air opening shows decrease in BSFC as compared to engine without turbocharger. And for $25 \%$ air opening there is slight change is observed as compared to engine without turbocharger.

\section{3) Volumetric Efficiency}

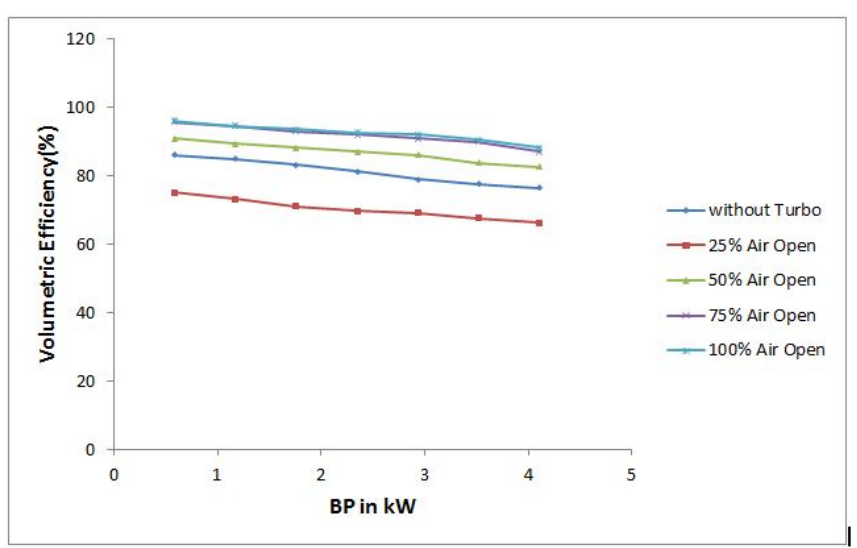

Fig.6 Variation of volumetric efficiency with brake power

The above Fig.6 shows that variation of volumetric efficiency with brake power for engine without turbocharger and with turbocharger at four different inlet opening conditions for diesel as a fuel. The density increase of intake air from atmospheric conditions represents the power gain that could be achieved by a turbocharged engine compared to a naturally aspirated engine of the same capacity. As the air is pressurized by the turbocharger it heats up, which decreases the ideal density gain that would occur under isothermal compression. Intercooler is used to increase the density of compressed air by cooling. There is increased volumetric efficiency for turbocharged engine of $100 \%, 75 \%$ and $50 \%$ air open conditions at $4.11 \mathrm{~kW}$ brake power is $10.14 \%, 9.63 \%$ and $4.94 \%$ respectively. For $25 \%$ even though engine is turbocharged there is decrease in volumetric efficiency because of decrease in area of air flow. 


\section{4) Peak Pressure}

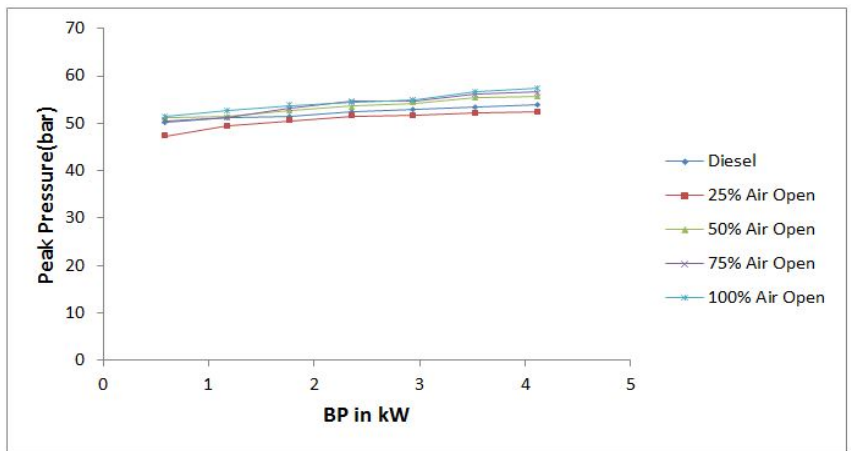

Fig.7 Variation of peak pressure with load

The above Fig.7 shows that variation of peak pressure with load for engine without turbocharger and with turbocharger at four different inlet opening conditions for diesel as a fuel. There is increase in peak pressure for turbocharged engine for $100 \%, 75 \%$ and $50 \%$ air opening but for $25 \%$ air opening peak pressure decreases due to lack of oxygen for combustion as compared to naturally aspirated engine. Increasing trend is almost same for $100 \%$ and $75 \%$ air opening because of more oxygen available for combustion, which helps for complete combustion of air fuel mixture and produces high power and shows a smooth combustion curve on P- $\Theta$ diagrams.

\subsubsection{Vibration Analysis of Engine using FFT}

\subsubsection{Vibration Analysis of Engine without}

\section{Turbocharger}

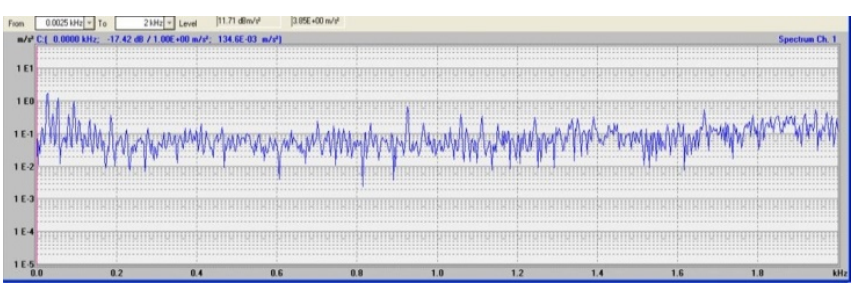

Fig.8 Frequency domain response of IC engine crankcase at no load

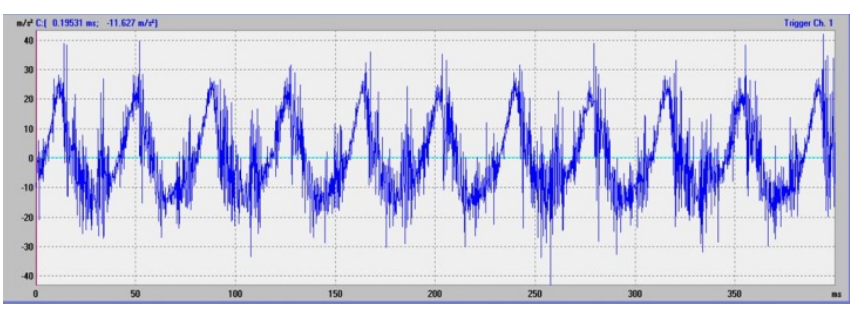

Fig.9 Time domain response of IC engine crankcase at no load

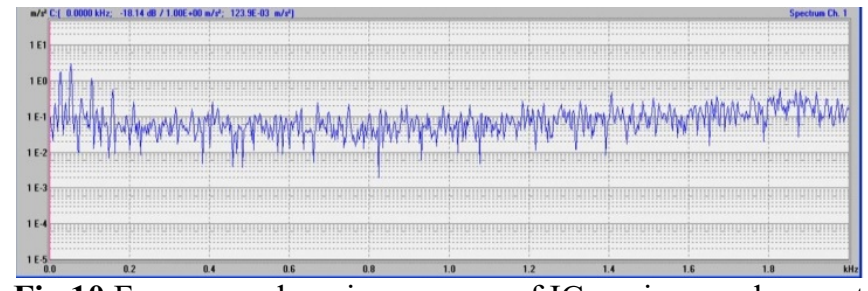

Fig.10 Frequency domain response of IC engine crankcase at $0.5 \mathrm{~kW}$ load

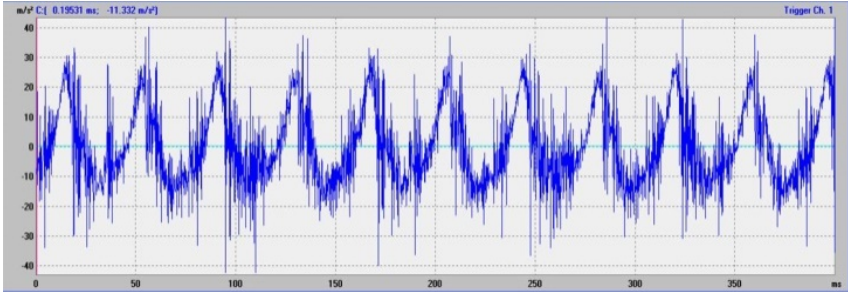

Fig.11 Time domain response of IC engine crankcase at $0.5 \mathrm{~kW}$ load

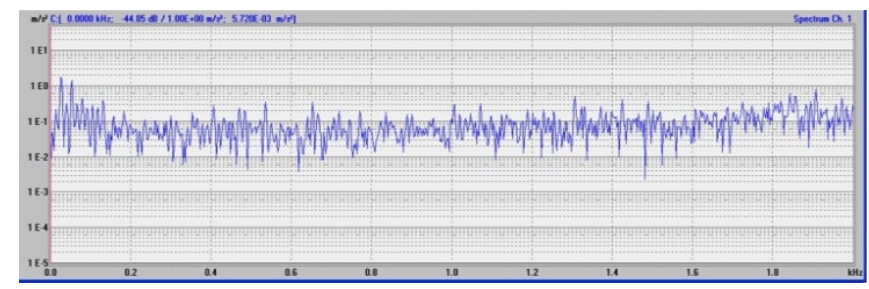

Fig.12 Frequency domain response of IC engine crankcase at $1 \mathrm{~kW}$ load

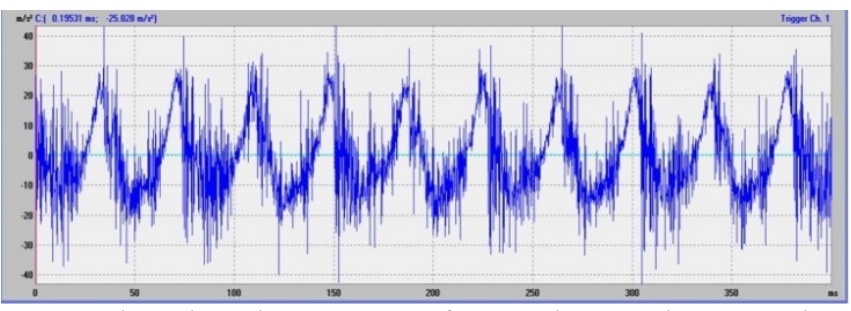

Fig.13 Time domain response of IC engine crankcase at $1 \mathrm{~kW}$ load

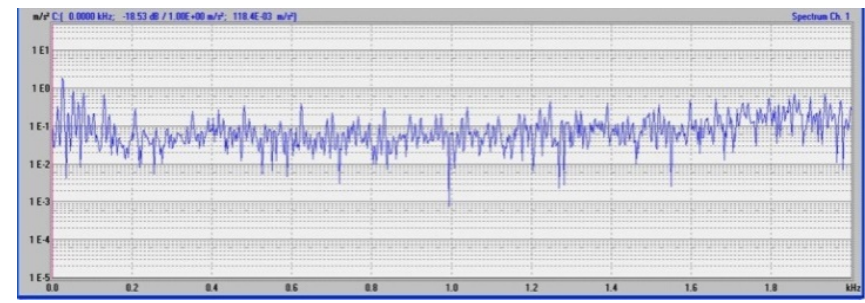

Fig.14 Frequency domain response of IC engine crankcase at $1.5 \mathrm{~kW}$ load

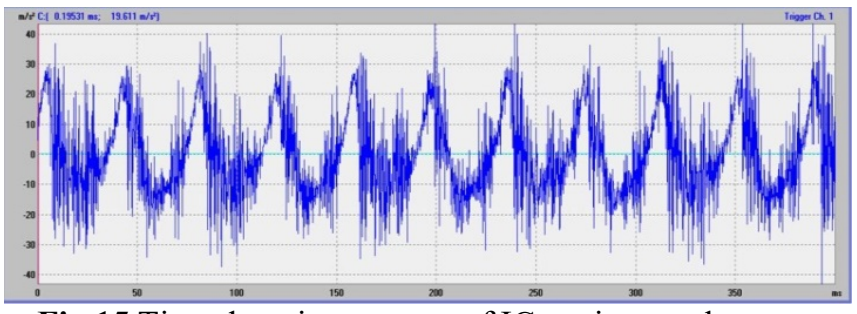

Fig.15 Time domain response of IC engine crankcase at $1.5 \mathrm{~kW}$ load

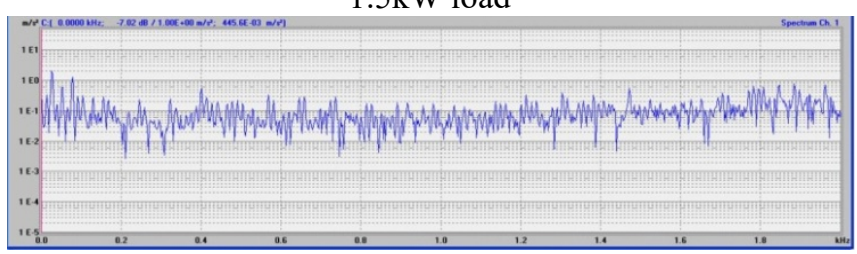

Fig.16 Frequency domain response of IC engine crankcase at $2 \mathrm{~kW}$ load 


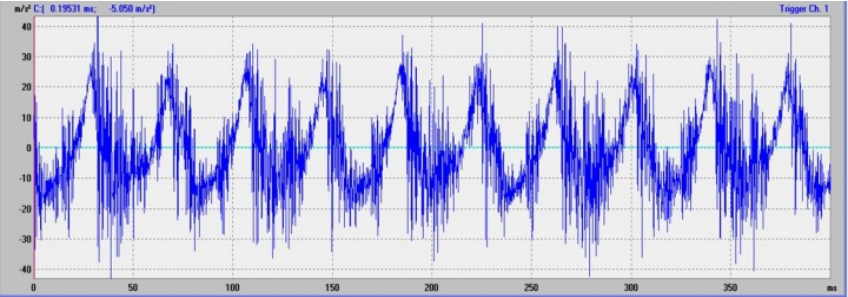

Fig.17 Time domain response of IC engine crankcase at $2 \mathrm{~kW}$ load

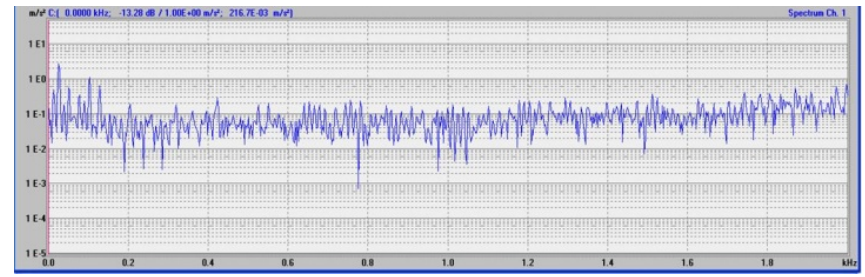

Fig.18 Frequency domain response of IC engine crankcase at $2.5 \mathrm{~kW}$ load

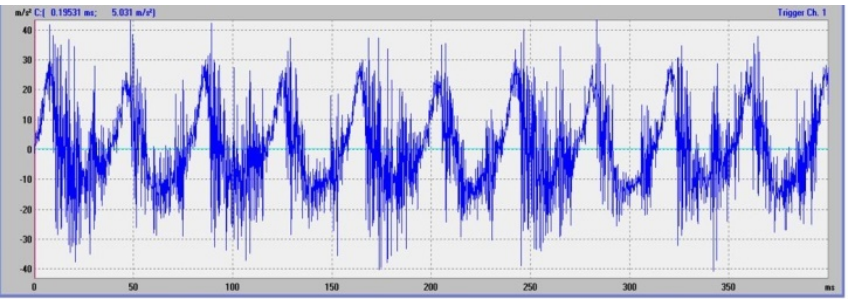

Fig.19 Time domain response of IC engine crankcase at $2.5 \mathrm{~kW}$ load

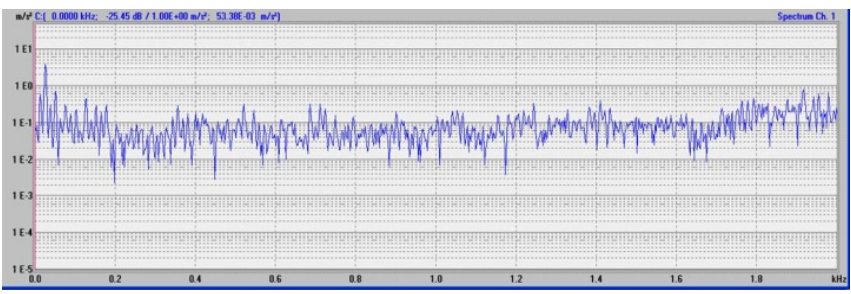

Fig.20 Frequency domain response of IC engine crankcase at $3 \mathrm{~kW}$ load

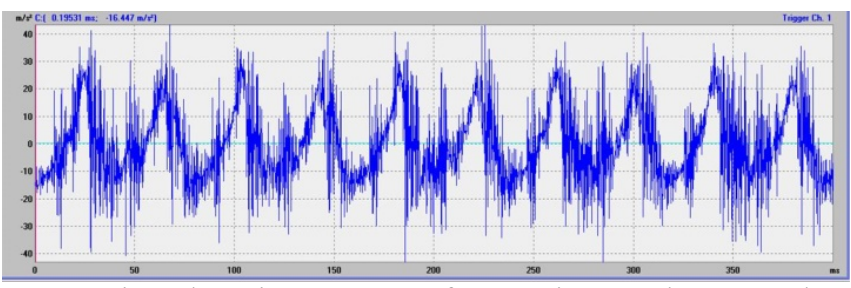

Fig.21 Time domain response of IC engine crankcase at $3 \mathrm{~kW}$ load

The above figures from Fig 8 to Fig 21 show the time and frequency response for naturally aspirated engine for no load to $3 \mathrm{~kW}$ load condition.

By taking the signatures of acceleration, vibration behaviour on IC engine crankcase for naturally aspirated engine following observations were made,

1) The vibrations amplitude ranging from $5 \times 10^{-3}$ to $446 \times 10^{-3}$ $\mathrm{m} / \mathrm{s}^{2}$

2) Peak value of acceleration $=446 \times 10^{-3} \mathrm{~m} / \mathrm{s}^{2}$
3) Amplitude of vibration are directly varying with respect to load

b) Vibration analysis of engine with turbocharger

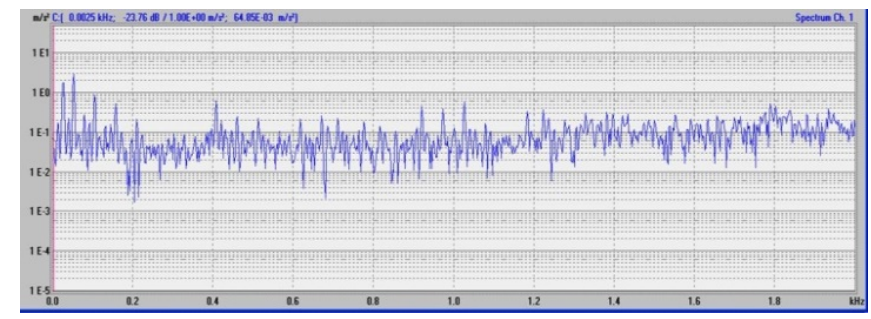

Fig.22 Frequency domain response of IC engine crankcase at no load

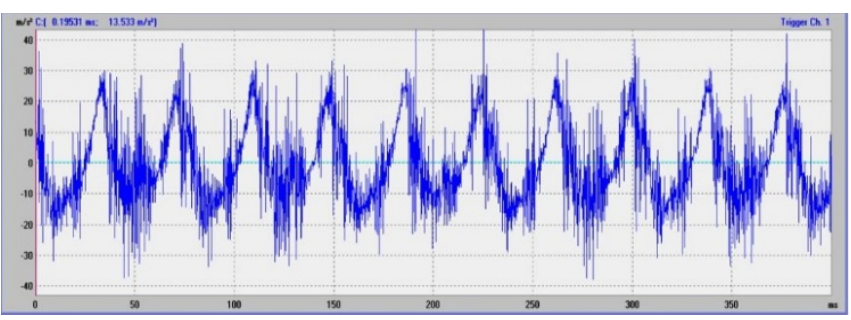

Fig.23 Time domain response of IC engine crankcase at no load

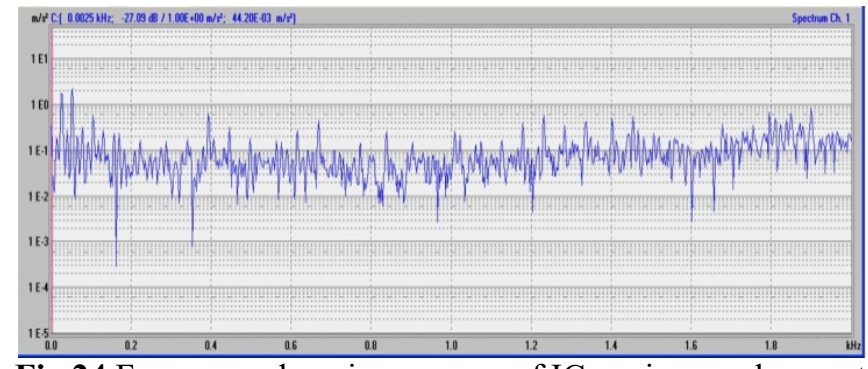

Fig.24 Frequency domain response of IC engine crankcase at $0.5 \mathrm{~kW}$ load

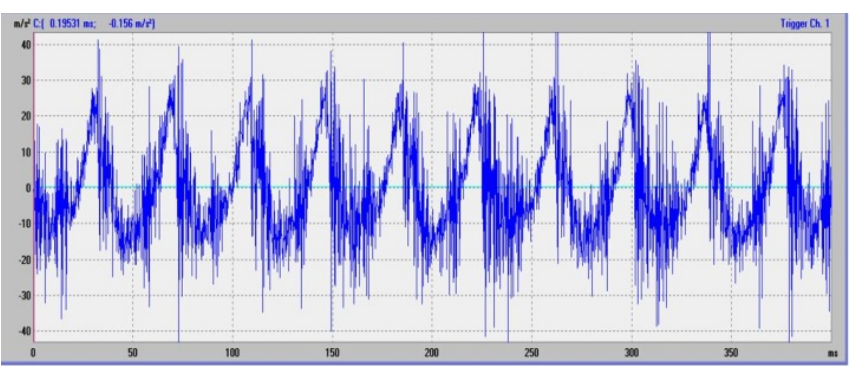

Fig.25 Time domain response of IC engine crankcase at $0.5 \mathrm{~kW}$ load

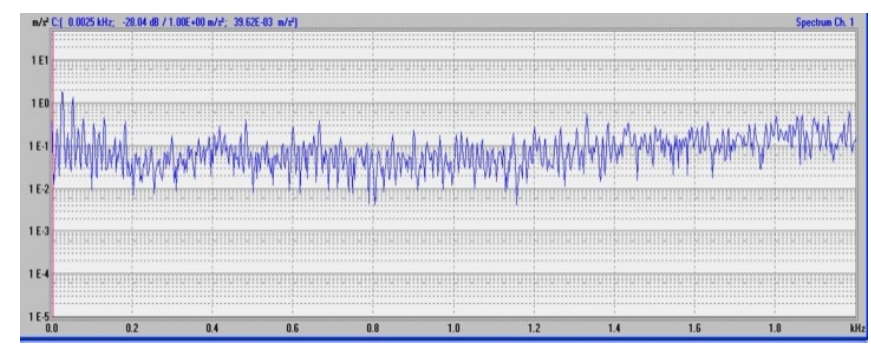

Fig.26 Frequency domain response of IC engine crankcase at $1 \mathrm{~kW}$ load 


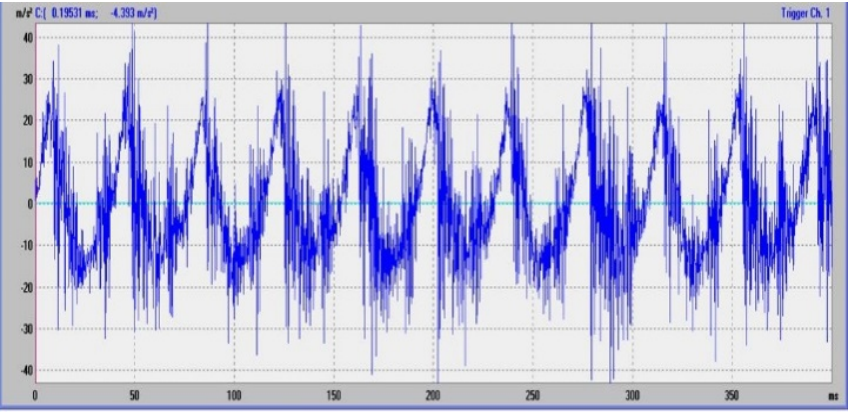

Fig.27 Time domain response of IC engine crankcase at $1 \mathrm{~kW}$ load

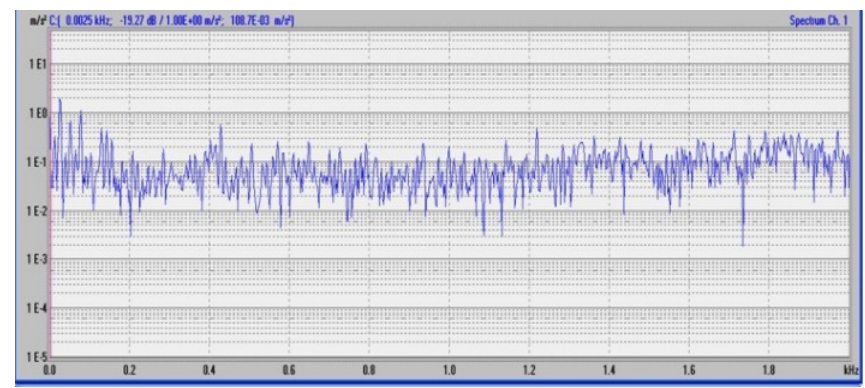

Fig.28 Frequency domain response of IC engine crankcase at $1.5 \mathrm{~kW}$ load

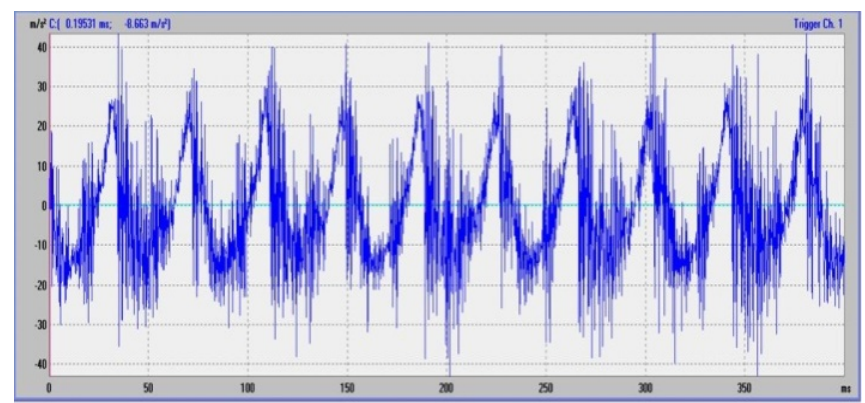

Fig.29 Time domain response of IC engine crankcase at $1.5 \mathrm{~kW}$ load

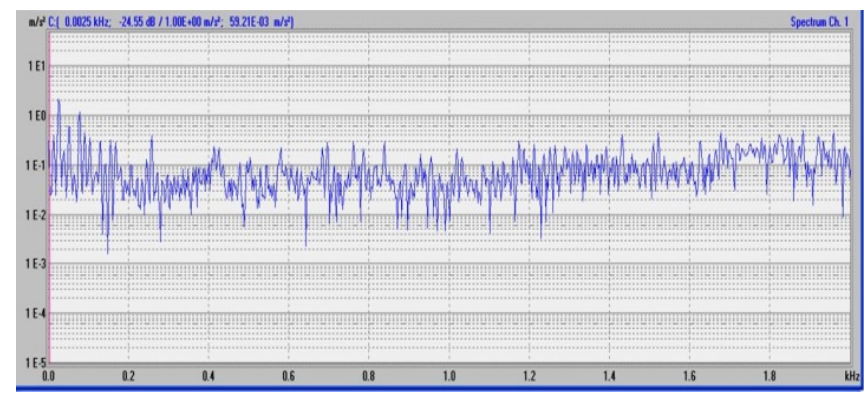

Fig.30 Frequency domain response of IC engine crankcase at $2 \mathrm{~kW}$ load

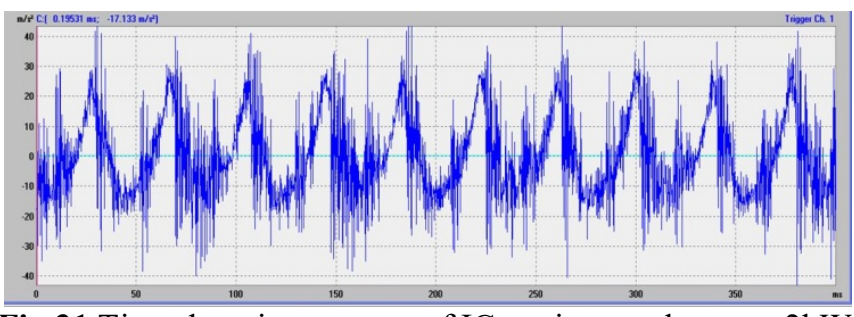

Fig.31 Time domain response of IC engine crankcase at $2 \mathrm{~kW}$ load

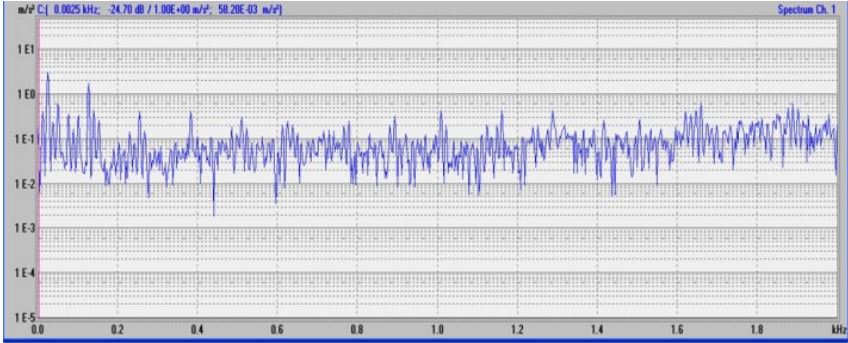

Fig.32 Frequency domain response of IC engine crankcase at $2.5 \mathrm{~kW}$ load

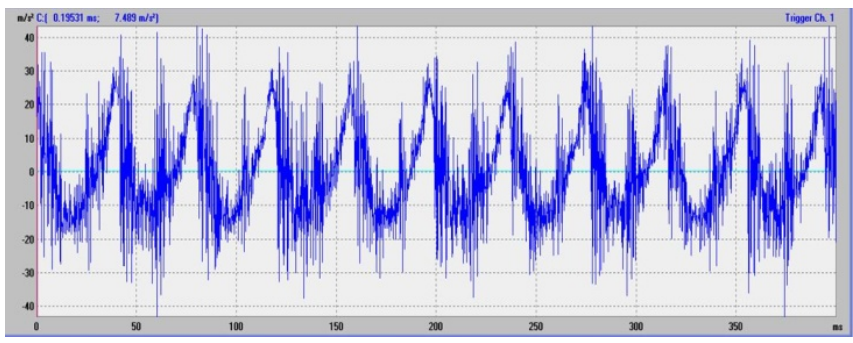

Fig.33 Time domain response of IC engine crankcase at $2.5 \mathrm{~kW}$ load

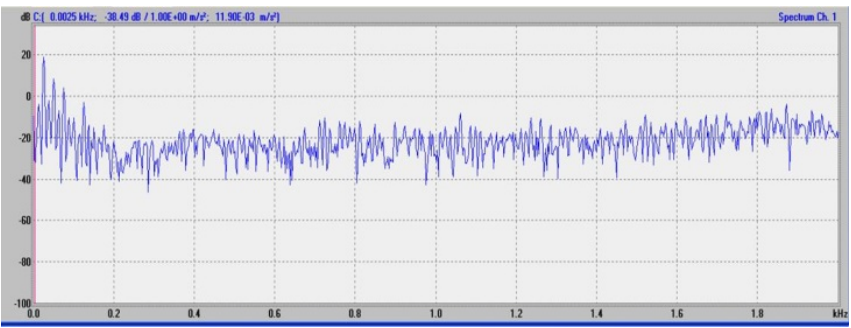

Fig.34 Frequency domain response of IC engine crankcase at $3 \mathrm{~kW}$ load

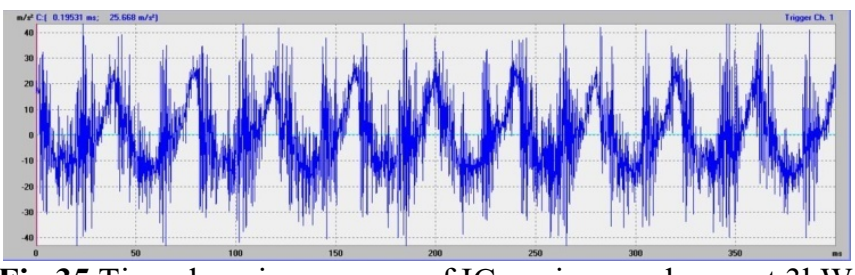

Fig.35 Time domain response of IC engine crankcase at $3 \mathrm{~kW}$ load

The above figure from Fig 22 to Fig 35 shows the time and frequency response for turbocharged engine for no load to $3 \mathrm{~kW}$ load condition.

By taking the signatures of acceleration, vibration behaviour on IC engine crankcase for turbocharged engine following observations are made,

1) The vibration amplitude ranging from $11 \times 10^{-3}$ to $109 \times 10^{-3}$ $\mathrm{m} / \mathrm{s}^{2}$

2) The peak value of acceleration $=109 \times 10^{-3} \mathrm{~m} / \mathrm{s}^{2}$

3) Here also increase in load gives increase in vibration amplitudes

4) Even though constant speed engine due to turbocharger boost threshold that is turbocharger starts producing boost only above a certain rpm due to a lack of exhaust gas volume to overcome inertia of rest of the turbo propeller. Thus results in a rapid and non-linear rise in torque, and will reduce the usable power band of the engine hence fluctuation in speed which causes the increase in amplitude of vibration. 


\section{CONCLUSION}

The current study mainly focused on the implementation of turbocharger to single cylinder diesel engine with exhaust modification to have more volume of exhaust for turbine of turbocharger and to control the air flow pressure, valve is adopted to air box and four different conditions such as $100 \%, 75 \%, 50 \%$ and $25 \%$ air open are analysed by comparing to naturally aspirated engine. Also vibration analysis of IC engine is made by using FFT analyser for both naturally aspirated engine and turbocharger engine.

After analysing the experimental results of engine performance parameters for both naturally aspirated and turbocharged engine following conclusions were made

1) Brake thermal efficiency increases for turbocharged engine as compared to naturally aspirated engine and found best at $100 \%$ air open condition.

2) Volumetric efficiency is increased for turbocharged engine due to increase in density of inlet air by using intercooler to reduce the temperature of compressed air.

3) There is decrease in brake specific fuel consumption for turbocharged engine as compared to naturally aspirated engine due to better mixing of fuel and air.

4) Due to complete combustion reduction in emissions reduced and also exhaust temperature were observed.

In the vibration analysis of single cylinder diesel engine with and without turbocharger at the range of 0 to $2 \mathrm{kHz}$ frequency range following conclusions are made,

1) Magnitude of vibrations defends on the engine speed which affects the vibration acceleration amplitude.

2) Vibration amplitudes also depend upon load on engines and for turbocharged engine vibrations were reduced after turbo lag.

\section{REFERENCES}

[1] A.G.Winter., "Turbocharged single cylinder internal combustion engine using an air capacitor" United States patent application publication Jan. 8, 2015

[2] Michael.R., "Method of turbocharging single cylinder four stroke engines" DETC 2014-35044

[3] Laukik .R., "Vibration analysis of IC engine using FFT analyzer" IJRET 2321-7308

[4] Dr.V. Ganesan., Internal combustion Engine, 3rd Edition, Tata McGraw-Hill Companies, New Delhi 2007, pp. 400-540.

[5]J.B.Heywood., Internal combustion Engine Fundamentals, 1988, Tata McGraw-Hill, pp.320-360

[6]. A. Kusztelan "A review of novel Turbocharger concepts for enhancements in energy Efficiency" Int. J. of Thermal \& Environmental engineering(2011) 75-82

[7]. A. Saini "Turbocharged single cylinder SI engine" 1 st International Conference on Research in science. Engineering and Management (2014)

[8]. C. Srinivasan "Increasing the efficiency of an engine by the use of variable geometry turbochargers" IJIRSET paper of 2nd National conference on trends in automotive parts system and applications (2014)
[9]. Dr. Jasbir Singh "Machines drive of power in farming in labour intensive state Haryana" GE-International Journal of Management Research (2015)

[10]. Deepa.P "Forecasting global turbocharger market: A mixed method approach"International Journal of Innovative research and development (2014)

[11]. H.Aulin "The effect of intake temperature in a turbocharged multi cylinder engine operating in HCCI mode" 2009-24-0060

[12]. Krishna Kumar "An outlook of turbocharging of IC engines" IRF International conference, 27th Sep. 2015

[13]. Michael.R "Method of turbocharging single cylinder four stroke engines" DETC2014-35044

[14]. R.Bisane "Experimental investigation and analysis of an single cylinder four stroke twin charge CI engine" IJRET 2321-7308

[15]. R.Kumar "Design and development of an integrated system for a conventional two wheeler by using high pressure of exhaust gases" IJIET 2319-1058

[16]. Rasik.S.K "Performance improvement of a DI diesel engine with turbocharging using biofuel" JMEST 3159-0040 (2015)

[17]. S.S Reddy "Effect of turbocharging on volumetric efficiency in an insulated DI diesel engine for improved performance" IJMER 2249-6645(2013)

[18]. Y. Gaikwad "Fabrication and implementation of turbocharger on two stroke vehicle" IJIERT 2394-3696 (2015)

[19]. Y. Jinnai "A variable geometry turbocharger for passenger cars to meet European Union emission regulations" Mitsubishi heavy industries technical review vol.49 (2012)

[20]. Laukik .R "Vibration analysis of IC engine using FFT analyzer” IJRET 2321-7308 